\title{
THE BETHEL AT NORWICH: AN EIGHTEENTH-CENTURY HOSPITAL FOR LUNATICS
}

\author{
by
}

\author{
MARK WINSTON *
}

The history of psychiatry has changed in recent years. One of the more exciting aspects of this change has been the move to examine primary clinical or administrative sources, to explore what was taking place within the developing profession and its institutional environment, and to relate this to its social and political surroundings. There are a number of such studies, on, for example, the Retreat at York, private madhouses in Oxfordshire, and Ticehurst.' The authors have had access to extensive surviving archives. These are predominantly the legacy of Victorian administrative reforms and have allowed remarkably detailed analysis and interpretation. Another feature of recent research has been its longitudinal or evolutionary perspective, which has revealed changes in disease categories or patient populations. ${ }^{2}$ Psychiatry is now seen in relation to its development, a process which has paralleled that of medicine over the last 300 years. Nineteenth-century studies have given us some detailed insight as far back as the early $1800 \mathrm{~s}$ but, in Porter's words, "what went before?". ${ }^{3}$ What preceded the nineteenth-century alienists and their asylums? Any answer is limited by the available evidence. There were few public institutions for the mad before the $1780 \mathrm{~s},{ }^{4}$ and most patients were in private care where there was no formal

\footnotetext{
* Mark Winston, MBBS, MRCPsych., Department of Psychiatry, University of Zimbahwe, P.O. Box A178, Avondale, Harare, Zimbabwe

' See, for example, Anne Digby, Madness, morality and medicine: a study of the York Retreat, 1796-1914, Cambridge University Press, 1985; W. Parry-Jones, The trade in lunacy: a study of private madhouses in England in the eighteenth and nineteenth centuries, London, Routledge and Kegan Paul, 1972; Charlotte MacKenzie, 'Psychiatry for the rich: a history of the private madhouse at Ticehurst in Sussex, 1792-1917', Psychol. Med., 1988, 18: 545-9.

2 See, for example, Anne Digby, 'The changing profile of a nineteenth-century asylum: the York Retreat', Psychol. Med., 1984, 14: 739-48; Charlotte MacKenzie, 'Social factors in the admission, discharge and continuing stay of patients at Ticehurst Asylum, 1845-1917', in William F. Bynum, Roy Porter and Michael Shepherd (eds), The anatomy of madness: essays in the history of madness, vol. 2, Ideas and institutions, London, Tavistock, 1985, pp. 147-74; Trevor Turner, 'Rich and mad in Victorian England', Psychol. Med., 1989, 19: 29-44; E. B. Renvoize and A. W. Beveridge, 'Mental illness and the late Victorians: a study of patients admitted to three asylums in York, 1880-1884', Psychol. Med., 1989, 19: 19-28.

${ }^{3}$ Roy Porter, Mind-forg'd manacles: a history of madness in England from the Restoration to the Regency, London, Penguin Books, 1990, p. 3.

${ }^{4}$ Public institutions for the mad before 1800 were, in order of establishment: Bethlem, a medieval hospital which had occupied new buildings in Moorfields in 1676, the Bethel in Norwich, built in 1713 and a public charity from 1724, St Luke's Hospital, opened in 1751 in Upper Moorfields, the Hospital for Lunatics at Newcastle-uponTyne (1765), the Manchester Lunatic Hospital, opened in 1766 next to the Infirmary, the York Asylum (1777), the Leicester Lunatic Asylum (1794), and the Liverpool Lunatic Asylum (1797).
} 


\section{Mark Winston}

requirement for record-keeping. Those records which were kept were of no more than local importance and have been subject to inevitable random damage and loss through time. Our knowledge to date has often been based on indirect sources, texts written by practitioners, or legal and other documentary material. ${ }^{5}$ However, analysis of institutional records for this earlier period has now begun and is bearing fruit. ${ }^{6}$

A number of mad-hospital archives exist intact for a significant part of the eighteenth century, including that of the Bethel in Norwich, which survives from $1724 .^{7}$ Although clearly not as well known as Bethlem, the Bethel has gained the unquestioned reputation of an atypical institution marginal to psychiatric development. ${ }^{8}$ However, as with Bethlem, all recent works quote one or two secondary sources, ${ }^{9}$ and none has examined the originals. ${ }^{10}$ This paper examines the surviving archive of the Bethel. ${ }^{11}$ The records were discovered in an outbuilding during the 1960s and have therefore been subject to damage and loss. However, a series of bound ledgers and minute books remain intact and provide an unbroken record of the administration of the Bethel. I intend to describe the organization and function of the hospital in its earliest years. I have chosen to study the period 1713 to 1814 for two reasons. First, this is a period for which little material is available or has been published. Second, during these years the Bethel was the sole public facility specifically for the mad or insane in Norwich; in 1814 the local county asylum was opened and this marked a major change in the pattern of local provision.

\section{THE FOUNDATION}

The Bethel was built in 1713. It was the idea of Mary Chapman, and her husband. The daughter of John Mann, one of the richest and most influential men in seventeenth-century

\footnotetext{
${ }^{5}$ See, for example, A. Fessler, 'The management of lunacy in seventeenth-century England: an investigation of quarter-sessions records', Proc. Roy. Soc. Med., 1956, 49: 901-7; Peter Rushton, 'Lunatics and idiots: mental disability, the community, and the Poor Law in north-east England, 1600-1800', Med. Hist., 1988, 32: 34-50.

${ }^{6}$ See, for example, Jonathan Andrews, 'Hardly a hospital, but a charity for pauper lunatics? Therapeutics at the Bethlem in the seventeenth and eighteenth centuries', in J. Barry and $\mathrm{C}$. Jones (eds), Medicine and charity before the welfare state, London, Routledge, 1991, pp. 63-81.

${ }^{7}$ The records of Bethlem for the eighteenth century survive. The archive of St Luke's Hospital, which survives from the date of its opening in 1751, is held in the modern hospital, St Luke's Woodside, Muswell Hill, London.

${ }^{8}$ Patricia Allderidge, "it was another unique institution, and does not really fit into any wider pattern" ("The history of the institutional care of the insane in England', in P. Pichot, P. B. Werner, R. Wolf and K. Thau (eds), Psychiatry: the state of the art, vol. 8, History of psychiatry, New York, Plenum Press, 1985, p.25); Joan Busfield, while mentioning the Bethel as the first charitable institution to be established after Bethlem, comments that "the first proper voluntary hospital for the insane ... was St Luke's Hospital ..." (Managing madness: changing ideas and practice, London, Unwin Hyman, 1989, p. 204); Porter states that "during the eighteenth century this asylum ... generally housed some twenty to thirty lunatics" (op. cit., note 3 above, p. 130).

${ }^{9}$ These are Sir Frederick Bateman and Walter Rye, The history of the Bethel at Norwich, Norwich, Gibbs and Waller, 1906, and Richard Hunter and Ida MacAlpine, Three hundred years of psychiatry, 1535-1860, Oxford University Press, 1963. Unfortunately, the former is of uncertain reliability, and the latter is limited in its scope.

10) The need to study primary sources was emphasized more than thirty years ago (Richard Hunter, 'Some notes on the importance of manuscript archives for psychiatric history', Archive, 1959, 4: 9-11), and the lack of primary research of the Bethlem archive in particular has been noted more recently (Patricia Allderidge, in 'Bedlam: fact or fantasy?' in Bynum, et al., op. cit., note 2 above).

1 The archive of the Bethel is held in the Norfolk Record Office (NRO). The eighteenth-century record includes minute books (draft and final) and account books from 1724, disbursement books from 1730, and numerous loose documents (bills, receipts, insurance notes, etc.).
} 


\section{The Bethel at Norwich}

Norwich, she came from a background of wealth and power. ${ }^{12}$ In 1682, at the age of thirtyfive, she married an older Anglican cleric, Samuel Chapman, the incumbent of Thorpe Episcopi, a parish just outside Norwich. Sadly, after eighteen years of marriage, she was widowed and left without children. Mary Chapman survived her husband by twenty-four years and it was during this time that her plans for the Bethel came to fruition. Her will still survives and gives an insight into the factors which influenced her plans. ${ }^{13}$ It is clear, for example, that she and her husband had discussed the idea of the Bethel before his death. Samuel Chapman had wished to provide a charity for those "deprived of . . . their reason". Her will states that the choice of name was his, and she prescribed certain Biblical texts to hang in the rooms. ${ }^{14}$ Both Mary and Samuel Chapman had immediate experience of lunacy in their own families. Her resulting sense of gratitude to God for her preservation of mind and a sense of compassion for those suffering were further powerful and explicit motives for her charity. ${ }^{15}$

On 12 December 1712, a lease was granted by the City Committee to four men, acting as trustees on behalf of Mary Chapman; a "wast peece of ground" was granted on a thousand year lease at a peppercorn rent. ${ }^{16}$ More significantly, the surviving deed specifies the purpose of the lease: "for the building a House or Houses for the benefit and use of such Persons as are Lunatics". ${ }^{17}$ The lease made no specific reference to pauper lunatics. The four trustees had sought and gained an empty plot of land on which to erect a house for the mad. One of the trustees, John Morse, undertook the building of the house and it was completed in 1713. We have little further information as to the initial management of the

\footnotetext{
12 John Mann was mayor of Norwich in 1653, sheriff of London in 1669, and High Sheriff of Norfolk in 1672. He served as a captain in the Norfolk Militia in 1650, and was held to be the leader of the Whig party in Norwich during the 1680s, at which time he was "the richest man in town" (B. Cozens-Hardy and E. A. Kent, The mayors of Norwich, 1403 to 1835, Norwich, Jarrold \& Sons, 1938, p. 87).

13 Mary Chapman's will is held in the NRO, MF 432.

$1+\ldots .$. and I will that these scriptures following shall be recorded on some stone or plank placed within the said house where my Trustees shall think best (that is to say): Jeremiah 9th, 23rd verse, let not the wise man glory in his wisdom; Corinthians, chapter 4, verse 7, Who maketh thee to differ from another; Ecclesiastes, 7th chapter, 7 th verse, Surely oppression maketh a man mad; Samuel 2 nd and 3rd, The Lord is God of knowledge and by Him actions are weighed", (Bateman and Rye, op. cit., note 9 above, p. 15).

15 "And whereas as it has pleased Almighty God to visit and afflict some of my nearest relations and kindred with lunacy, but has hitherto blessed me with the use of my reason and understanding as a monument of my thankfullness unto God for this invaluable mercy and out of a deep sense of His divine goodness and undeserved love to me vouchsafed and in compassion to the deplorable state of such persons as are deprived of the exercise of their reason and understanding and are destitute of relations or friends to take care of them and also because it was much on my good husband's thoughts to contribute something towards perpetual maintenance of this particular act of Charity, for all and every of these reasons my Will is that the House I have lately built in the Parish of Saint Peter's Mancroft ... shall by my said trustees... from time to time for ever after be used and employed for the convenient reception and habitation of poor lunaticks which it shall be called according to the desire of my said well beloved husband by the name of Bethel . .."; extract of Mary Chapman`s will transcribed in Bateman and Rye, op. cit., note 9 above, pp. 14-15.

${ }^{16}$ The lease on the site of the Bethel, Norwich City Records (NCR), Case 22, Shelf d, No. 8.

${ }^{17}$ The text of the lease reads, "Att a Meeting of the City Committee the Twelfth day of December Anno Dom 1712 with William Cockman Esq John Hall Esq Mr John Morse Mr Timothy Greene Trustees for the Charity of Mrs Mary Chapman relict of Samuel Chapman late of Norwich Thorpe for the building a House or Houses for the benefit and use of such Persons as are Lunatics. It is agreed by the said Committee at the request of the said Trustees that they or their successors shall have a Lease of a wast peece of ground next the House commonly called the Committee House in the parish of St Peter of Mancroft in Norwich aforesaid from the East End the house of Thomas Fawkener now in the [illegible] of Thomas Allyson to the outside of the Pillar of the School now used by Mr Bernard Church in the said parish next the Queen`s High Way”. Ibid.
} 
Bethel, or of the remaining years of Mary Chapman. The foundation stone in the front entrance reads:

This house was built for the benefit of distrest Lunaticks Ano Dom. 1713 and is not to be alienated or employed to any other use or purpose whatsoever. Tis also requir'd that the Master, who shall be chosen from time to time, be a Man that lives in the Fear of God and sets up the true protestant Religion in his Family and will have a due Regard as well to the souls as bodies as those that are under his care.

In a codicil to her will dated 22 October 1719 she described herself as living "with the widow Taylor", and stated that one Henry Harston was in charge of the house. At some time during the next four years Mr Harston died and a new Master, Robert Waller, was appointed. Both of these men appear to have been laymen with no medical qualification. Apart from these clues no records survive from these early years (if any were made) and there is no evidence as to the nature of the Bethel, its residents or its administration while it remained in private ownership. There is no record of the admission or management of lunatics, appointment of staff or an active role for trustees before Mary Chapman's death.

Norwich had a long history of individual charity. ${ }^{18}$ Many public institutions of the eighteenth century depended on large donations or bequests by wealthy patrons. ${ }^{19}$ In 1729 Bethlem received almost the entire benefit of the estate of Edward Barkham towards

\footnotetext{
18 The oldest charity in Norwich was the Great Hospital founded by Bishop Suffield in 1256. More typical of the type and scale of the Bethel endowment were the Children's Hospital, endowed by Thomas Anguish and built in 1620, Doughty's Hospital, established in 1704 on an endowment of $£ 6,000$ by William Doughty, and Norman's Endowed School, established in 1724 by John Norman, mayor of Norwich in 1714. Thomas Doughty's will laid down that land should be bought in Norwich for a house and garden to accommodate twenty-four men and eight women. Domestic responsibility was given to a Master, who was to be a single man, and the administration of the endowment was left to five trustees (J. Hooper, Norwich charities: short sketches of their origins and history, Norwich, 1898, pp. 45-83). There was also scope for personal charity on a smaller scale. For example, Thomas Hall, son of one of the original trustees, died in 1715 leaving $£ 200$ to the Bethel, $£ 200$ for a monthly lecture in the city of Norwich, $£ 100$ between the Church of England and the Dissenters schools and $£ 100$ for a gold chain to be worn by the mayors of the city (F. Bloomfield, An essay towards a topographical history of the county of Norfolk, vol. 3, London, 1806, pp. 436-7). Samuel Chapman, the husband of the foundress of the Bethel, left $£ 200$ to Doughty’s Hospital in his will. Two of the trustees to the Bethel in the 1760s, Jehosophat Postle and Thomas Vere, also gave or bequeathed $£ 200$ each (Hooper, op. cit., see above, p. 48). A number of the trustees of the Bethel were involved with other charitable institutions in Norwich, either through donations or bequests, or by working in their management. For example, Philip Meadows was treasurer and receiver to Doughty's Hospital in 1745 (Hooper, op. cit., see above, p. 47). A number were specifically involved with the Guardians of the Poor, an institution established in Norwich by Act of Parliament in 1711. The Act made Norwich one parish with regard to the poor and provided for three workhouses. The Guardians were elected annually, and included the mayor, recorder, steward, JPs, sheriffs and aldermen, "thirty-two other persons ... eight out of each great ward" and "such other persons as shall give 50l. or more towards the workhouses...". These men stood as Guardians for one year and elected out of their number a governor, a deputy governor, a treasurer, and twenty assistants. They met on the first Tuesday of each month. They could bind children of sixteen years or less by indenture for up to seven years, and could take up "rogues, vagrants, sturdy beggars, idle, lazy or disorderly persons" into the house of correction and make them work for up to three years (in Blomfield, op. cit., see above, vol. 3, p. 432). The composition of the Corporation was similar to that of the Bethel, while the method of election looked forward to the voluntary subscription system.

${ }^{19}$ Charitable giving continued throughout the eighteenth century. In some respects, voluntary subscriptions represented a form of institutionalized charity. Larger endowments included Guy's Hospital, established on the bequest of Thomas Guy in 1725. John Radcliffe (died 1714) and John Addenbrooke (died 1719) both left large parts of their estates to establish general hospitals. Their eponymous institutions may have been voluntary subscription hospitals, but their initial bequests were personal and generous. See J. Woodward, To do the sick no harm: a study of the British voluntary hospital system to 1875, London, Routledge and Kegan Paul, 1974, p. 15.
} 


\section{The Bethel at Norwich}

establishing wards for incurables. ${ }^{20}$ The fact that the Bethel was founded, and initially maintained, on one individual's personal charity was not remarkable. What is interesting is that this charity should have been so specifically directed towards the mad from its beginning. The particular reasons, apart from the personal ones evident from Mary Chapman's will, remain unclear, although evidently she and her husband were influenced by religious motives and there was a strong element of concern for the welfare of distracted souls. But such personal charity needed a receptive community to flourish. In 1700 Norwich was the largest city after London with a population approaching 30,000 ; its closest rival, Bristol, had a population of more than $20,000 .^{21}$ There was a tradition of local initiatives directed towards the poor. A census of the city's poor in 1570 included three individuals who appeared to be mentally disturbed, ${ }^{22}$ and provision had been made for medical and surgical care. ${ }^{23}$ Eighteenth-century Norwich had a strong dissenting tradition and Quaker families were to be of great importance to Norwich and the Bethel. Political life was heavily influenced by the Whig party. Mary Chapman came from a leading Whig family and many of the trustees in the early years of the foundation were prominent Whigs. This combination of personal, religious, and political factors provided the right conditions for the Bethel to be built and established.

\section{THE TRUST}

The nature of the Bethel changed dramatically with the death of Mary Chapman on 8 January 1724 . From then on it was a public charity run by trustees for a specific purpose. This was only four years after the opening of Westminster Hospital and forty-eight years before that of the local general voluntary hospital, the Norfolk and Norwich, in 1772. St Luke's Hospital would not be established for a quarter of a century. Mary Chapman's will directed the trust to provide for "the convenient reception and habitation of poor lunaticks", not "such as are fools or idiots from their birth". ${ }^{24}$ She recognized the well established distinction between those with congenital idiocy and those with lunacy of more recent onset. ${ }^{25}$ The will also revealed something of Mary Chapman's specific concern for poor lunatics which was not mentioned in the City Committee's lease. The trust's first duty was to those lunatics who were "poor inhabitants in the said City of Norwich or elsewhere... always preferring such persons [from] Norwich"; "care, maintenance and relief of them for clothes, food, and physick, and all other necessaries"

\footnotetext{
20 "... laid upon the heart and conscience of Edward Barkham to leave to Bethlem for the maintenance of incurable wards nearly all that he had in lands and houses in Lincolnshire", E. G. O'Donoghue, The story of Bethlem Hospital from its foundation in 1247, London, T. Fisher Unwin, 1914, p. 244.

${ }^{21}$ See P. J. Corfield, The impact of English towns 1700-1800, Oxford University Press, 1982, p. 15.

22 See J. F. Pound (ed.), The Norwich census of the poor 1570, Norwich, Norfolk Record Society, vol. 40, 1970.

${ }^{23}$ See Margaret Pelling, 'Healing the sick poor: social policy and disability in Norwich 155()-1640", Med. Hist., 1985, 29: 115-37, and A. Batty Shaw, 'The Norwich school of lithotomy', Med. Hist., 1970, 14: 221-59.

${ }_{24}$ Quoted from the transcription of the will in Bateman and Rye, op. cit., note 9 above, p. 15.

${ }^{25}$ See Rushton, op. cit., note 5 above; R. Neuberger, 'Diagnosis, guardianship, and residential care of the mentally ill in medieval and early modern England', Amer. J. Psychiat., 1989, 146: 1580-4. In 1700, John Rydall published Law relating to natural fools, mad-folks, and lunatick persons, described as the first "Collection ... of such laws . . as do properly concern the Rights of all such, as are wholly destitute of Reason: Some whereof become so by a perpetual Infirmity, as Idiots, or Fools Natural... Some, that have their lucid Intervals, (sometimes in their Wits, sometimes out), as Lunatick Persons..." (quoted in Hunter and MacAlpine, op. cit., note 9 above, p. 278).
} 


\section{Mark Winston}

were to be the responsibility of the trustees. The terms of the will refer next to "any person or persons in the said County of Norfolk or elsewhere afflicted with lunacy, [whose] relations or friends desire to place them in the said House of Bethel"; in these cases "though poor persons, yet their relations or friends shall, according to their ability, pay something by way of acknowledgement to my said trustees ...". Finally, lunatics "of ability" could be admitted; their friends or relations were to be responsible for "all charges on account of such persons or persons" and also pay a negotiated fee. The proceeds of such admissions were to expand the reserves of the trust "for the further benefit and improvement of the said charity". The foundress made two other stipulations in her will: "those put ... into the said House shall be kept close and not suffered to wander abroad during their disorder, nor shall they continue in the said House any longer than their lunacy or madness is upon them and they be restored to possession of themselves ..." ${ }^{26}$ From the outset, Mary Chapman intended her house to be a place of confinement which would facilitate recovery, and she was explicit that the former should not be abused at the expense of the latter.

The will named seven trustees who met for the first time on 12 January $1724 .^{27}$ One had predeceased Mary Chapman, and by the following May two more had resigned. The trustees were empowered with full authority over the Bethel and were able to appoint replacements to their number directly. The first business of the committee was to elect Sir Benjamin Wrench to replace Richard Cooke. ${ }^{28}$ Timothy Ganning resigned on 10 May 1725 , "through my age and some business that is unavoidable on my hands", and he was replaced by Philip Meadows. ${ }^{29}$ Their first priorities were to ensure a full committee of trustees and to make basic administrative arrangements. At their first meeting it was "also agreed that proper books be provided to begin and enter all our proceedings in". ${ }^{30}$ On 10 March it was decided to appoint "the following Offices ... a physician, a Treasurer, a Clark and a Master of the House"; Sir Benjamin Wrench was appointed physician, William Lockman treasurer, John Lombe clerk, and Robert Waller was retained as Master of the Bethel. ${ }^{31}$ Shortly afterwards the first three were granted honoraria of $£ 16$ per annum, and the last a salary of $£ 30$ per annum. This is the first record of administrative organization and the first reference to medical staff. These offices, common among later voluntary institutions, were maintained throughout the period covered by this paper. ${ }^{32}$ The

\footnotetext{
${ }^{26}$ Quoted from the transcription of the will in Bateman and Rye, op. cit., note 9 above, pp. 15-17.

27 The seven original trustees were John Hall, William Cockman, John Lombe, John Thompson, Timothy Ganning, Richard Cooke, and William Lombe. William Cockman, John Lombe, and John Thompson were weavers, while Timothy Ganning was an upholsterer (Cozens-Hardy and Kent, op. cit., note 12 above; P. Millican, The register of freemen of Norwich 1548-1713, Norwich, Jarrolds, 1934).

${ }^{28}$ Minute of 12 January 1724.

${ }^{29}$ Minutes of 10 May and 16 August 1725.

${ }^{30}$ Minute of I February 1724. The waste books and final journals are preserved in the NRO in two series, BH9-BH15 and BH16-BH20. "Minute(s)" in the following notes are referenced by date alone.

${ }^{31}$ Minute of 22 March 1724.

${ }^{32}$ These posts were almost universal in eighteenth-century hospitals. Most formally elected a treasurer and many had a clerk or secretary. Such administrative offices were established at St Luke's Hospital and at the Royal Salop Infirmary (see C. N. French, The story of St Luke's Hospital 1750-1948, London, Heinemann, 1951, p. 20, and W. B. Howie, 'The administration of an eighteenth-century provincial hospital: the Royal Salop Infirmary, 1747-1830', Med. Hist., 1961, 5: 34-55). A treasurer was appointed at Westminster Hospital (J. G. Humble and P. Hansell, Westminster Hospital 1716-1966, London, Pitman Medical, 1966, p. 133).
} 


\section{The Bethel at Norwich}

implication from the minutes is that they had not existed previously. The pattern of committee meetings was established from an early date. They took place at the Bethel every four weeks, and the Master reported on the number of lunatics resident and the state of the house. The clerk reported the fees received and paid these to the treasurer. The Master presented his bills for the house for payment by the treasurer, and other tradesmen's bills might also be tendered.

These were routine items. Another important task for the committee was the investment of the bulk of Mary Chapman's estate, a total of $£ 3,51311 s 4 d$. The first of a series of investments relating to property was made in 1725: "had treated and also agreed with a Capt Pell for lands at Pulham-£750".33 In 1759, the trust had three tenants in Potter Heigham, two in Pulham St Mary, and one each in Kirkstead and Ludham, providing annual rents of $£ 23010$ s. By 1806 , the annual rents from eight tenancies amounted to $£ 85510 s .{ }^{34}$ Such estates provided a further source of income through the sale of produce. Large sums of money were also invested in bank annuities. The first clear reference to this was in 1748 and by the end of the century approximately $£ 13,000$ had been invested in this way. The trustees also gave loans from which the trust gained interest. ${ }^{35}$

The trustees of the Bethel tended to be drawn from the Whig party in Norwich. During the first decades of the trust almost half the trustees held high office for the Whig party. ${ }^{36}$ Two of the trustees to the will served as mayor, John Hall in 1701 and 1719, and William Cockman in 1711. By the end of its first hundred years the composition of the committee had changed. Its members were drawn from the new manufacturing and banking families, the most notable in retrospect being members of the Gurney family. ${ }^{37}$ However, the civic and religious connections remained, albeit changed in detail from Anglican and aldermanic to Quaker and financial. The legal basis for the trust also altered in 1765 when it gained incorporation, and the trustees became governors. ${ }^{38}$ The Bethel differed from later subscription hospitals in having no list of subscribers or contributors whose donations bought privilege or voting rights within the trust. However, the list of trustees and governors suggests that a combination of political, social, and religious factors played their part in the formation of the committee. ${ }^{39}$ The trustees and, later, the governors, limited to seven at any one time, enjoyed complete authority over the Bethel and its administration. Apart from their legal obligations, first under the terms of Mary

\footnotetext{
${ }^{33}$ Minute of 31 May 1725.

${ }^{34}$ See General Account Book (NRO BH1), and the minute of 19 March 1806.

${ }^{35}$ For example, $£ 1,000$ was loaned to the Corporation at 4 per cent interest in 1739, minute of 1 October 1739.

${ }^{36}$ Of the twenty-four trustees appointed in the first fifty years of the trust, ten held office as mayor; in all cases they were Whigs. In 1742 alone, six trustees acted as Justices of the Peace (Cozens-Hardy and Kent, op. cit., note 12 above; Blomfield, op. cit., note 18 above, vol. 3, pp. 436-7).

${ }^{37}$ Five members of the Gurney family served as governors. The first, John Gurney, was appointed in 1792 and the last, another John Gurney, in 1867. The banking and Quaker connections were also reflected in the appointment of two members of the Birkbeck family, banking partners of the Gurneys.

${ }^{38}$ The minutes record an "Abstract of the Powers granted to the Trustees . . . by a Royal Charter ... dated at Westminster 8th day of June 5 Geo 3rd". These powers included full authority in law, business, property, etc. and in relation to staff. The trust was granted a common seal. The committee of governors was to meet on the first, second or third Monday of each month when the senior governor present was to take the chair, and the committee was empowered to form sub-committees. The treasurer's length of office was limited to three years (minutes of 1 July 1765).

${ }^{39}$ For example, Thomas Vere, Whig MP and mayor, made a number of charitable donations to the parish of Thorpe Episcopi and served as a trustee from 1732; his son, John Vere, also served as trustee. Jeremiah Ives and
} 


\section{Mark Winston}

Chapman's will and later the charter, they were not responsible to any other body for the maintenance of the committee or the running of the hospital.

Although the trust was independent financially, the Bethel still received gifts and bequests. Such income was probably a useful, if not always essential, addition to that from fees and investments. A charity box for visitors' donations provided a steadily diminishing source of income, never more than 10 or 15 per cent of the revenue from fees. More substantial donations were recorded in the board room, and, together with the fees, made up the bulk of the hospital's income. From the limited figures for these gifts and the annual returns for fees it is possible to estimate the proportion of the Bethel's gross income derived from charity. Total charitable giving of $£ 100$ or more ranged from less than 20 per cent of total income in the 1740s, 1770s and 1790s to more than 40 per cent in the 1780s. During this latter period the amount received from charitable gifts was at least three-quarters of that from fees. ${ }^{40}$

The first recorded "Rules or Byelaws" were established in 1728. "I These formalized the pattern of meetings on a four-weekly basis and gave any four trustees full powers to transact business. $^{42}$ General Meetings were to be held on every fourth Monday, with Special Meetings to be called for "business of moment". Resolutions were to be recorded in a "Wast-book", and signed by each trustee present, and the final minutes in the Journal Book were to be presented and signed at the next meeting. ${ }^{43}$ Workmen had to be approved by the trustees, and no bills were to be paid without a prior warrant from the committee. Patients were admitted at the monthly committee. A rough draft of the form of certification and warrant remains inside the cover of the first waste book: ${ }^{44}$

For the trustees:

City \& County of Norwich

January 1730

We whose names are herein Subscrib'd being appointed Trustees for the Endowment of Bethel do require you on Sight hereof to take and Receive into the aforesaid House - take

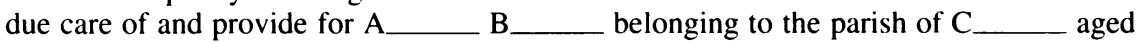
about ___ years He being Certify'd under the hand of our Physician to be under Lunacy

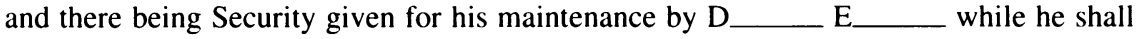
continue there to our Satisfaction.

To $\mathrm{F}$ G.

Robert Waller

Keeper of Bethel

\footnotetext{
Jehosophat Postle acted as churchwardens and trustees; the former, a prominent Whig, also served as mayor (see W. R. Supple, A history of Thorpe-next-Norwich, otherwise Thorpe Episcopi and Thorpe S. Andrew, Norwich, Jarrolds, 1918).

40) The larger gifts and bequests were recorded on panels on the walls of the committee room. Recorded gifts of more than $£ 100$ totalled $£ 500$ in $1730-9, £ 452$ to $1749, £ 1,100$ to $1759, £ 1,600$ to $1769, £ 750$ to $1779, £ 2,1(0)$ to 1789 , and $£ 500$ to 1799 . There were two gifts of $£ 1,000$ in 1750 and 1766 .

+1 Minute of 27 May 1728.

42 From the time of the establishment of the Royal Salop Infirmary four of the trustees were required for a quorum, but only three directors were needed from 1792 (Howie, op. cit., note 32 above, p. 37). At St Luke's Hospital, five members of the General Committee were required to do business (French, op. cit., note 32 above, p. 191).

${ }^{43}$ At the Royal Salop Infirmary both draft and final minutes were kept, and the names of patients admitted and discharged were also recorded (Howie, op. cit., note 32, p. 37).

${ }^{+4}$ Minute Book NRO BH9.
} 


\section{The Bethel at Norwich}

For the applicants:

Norwch Janry 1730

Having this Day receiv'd an order from the Trustees for the Endowment of Bethel directed to the Keeper to Receive \& take into the aforesaid House, take care of \& provide

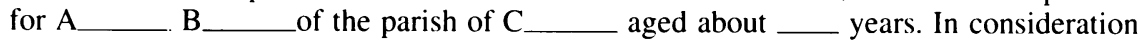

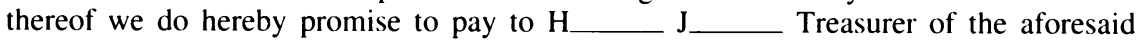
Endowment or to his order the Summ of Four Shillings per Week and to pay the Same Monthly for so long time as he shall remain in the aforesaid House and also to allow for all Damages and Wasts that shall be committed by the said A__ B_ and to Supply him with necessary Cloathing during his abode there, and if he shall dye there, do promise to remove the Corps or else to be at the charge of Burying him from the aforesaid House in witness whereof we now Set our Hand the Day and Year above written.

The process of admission had three components. Admission ultimately required the authority of three trustees; the committee was also responsible for discharge. However, it depended on two other factors as well. One was examination and certification of lunacy by the physician to the Bethel. No details of the place or procedure involved are given but the minutes record patient admissions and discharges on a monthly basis, suggesting that examination occurred at frequent and regular intervals. The other was security for maintenance. This included clothing, future costs of burial, and the costs of any damage their charge might cause. While the first two of these were common features of eighteenth-century hospital administration, the last was not. ${ }^{45}$ Most voluntary hospitals explicitly excluded the insane from admission along with the pregnant, the infectious and the incurable. In the 1750s lunatics were admitted to the Manchester Royal Infirmary but the fees were set to take account of their dangerous and damaging potential. ${ }^{46}$ The care of lunatics was accepted as potentially expensive and these costs were reflected in the terms of admission.

This form of application also contains the first reference to a standard fee set at four shillings a week. By the end of the century this had increased to $4 s 6 d$ and in 1801 it was decided that "in consideration of the great Advance of every necessary of life the weekly pay of the Patients be augmented from $4 / 6$ to $6 s$ p. week....47 Despite the acknowledgement that unusual expenses attached to the patients at the Bethel, these rates

\footnotetext{
${ }^{45}$ Compare this with the situation at St Luke's Hospital. A petitioner had to obtain two certificates (one signed by a minister and two churchwardens, the other by a physician, apothecary or surgeon), take an oath as to their authenticity, and then present them, together with a formal petition, to be signed by a governor and registered with the secretary. The petitioner was required to attend the next general Committee and, if successful, the patient was brought for examination. Seven days notice was given for discharge and a bond of $£ 100$ was required against this (French, op. cit., note 32 above, pp. 192-3, 197-8). In general, admission to voluntary hospitals in England required the recommendation of a subscriber, a deposit against the costs of washing and possible burial, and examination by the physician or surgeon appointed to the hospital (Woodward, op. cit., note 19 above, pp. 23, 38-40).

th At the Manchester Royal Infirmary, established in 1752, it was felt that "in consideration of the extraordinary Guard and Attendance which they will require, a Sum not less than Five Shillings weekly" was the appropriate fee for poor lunatics (N. Roberts, Cheadle Roval Hospital. A bicentenary history, Altrincham, Sherratt and Son, 1967, p. 4) while the standard charge at its daughter institution, the Manchester Lunatic Hospital, in 1767, had risen to "not less than ten shillings a week" (Porter, op. cit., note 3 above, p. 132); a doubling of charges in fifteen years.

${ }^{47}$ Minute of 6 April 1801 .
} 


\section{Mark Winston}

were low by comparison with those of other institutions. ${ }^{48}$ As early as 1729 the trustees had negotiated a special rate with the Corporation of Guardians of the Poor ${ }^{49}$ The earliest records of patients in the minutes refer to the admission "on the Foundation" of poor patients, who could not pay fees. The overall numbers of patients were recorded regularly from the early 1730 s but the specific numbers of patients "on the Foundation" were not noted until $1764 .^{50}$

The original house is known only from its image on the seal of the Bethel and from a written description. ${ }^{51}$ It seems to have been a two-storey building with two wings, set back from the road, then known as Committee Street. There are no records of the accommodation available nor of how many were resident at the inception of the trust. However, within little more than two years the trustees felt it necessary to enlarge the building. In 1727, six new wards were commissioned and other building work was undertaken. ${ }^{52}$ The next wave of expansion occurred in the late 1740s and 1750s. In 1747, it was ordered that "Thomas Benning, Carpenter, do make a partition in each story in order that the Mens apartments may be wholly on one side of the Hospital and the Womens on the other. And also that he make a new Window on the South side of that Cellar where some of the Lunatics are lodged". 53 The inference is that the sexes had not previously been physically separated into different halves of the house but had occupied some form of intermixed accommodation within it. In 1749, the bathroom was converted to a cell, and the strawroom to a "Cellar for the worst of the Lunatics to be put in", in accordance with the contemporary practice of placing difficult patients in cellars or basements. At the same time a new strawhouse, bathroom and wash-house were to be built, ${ }^{54}$ while, a year later, a bathroom was again converted to a two-bedded cell. Here are some of the elements of the stereotypic Georgian mad-house: segregation of the sexes, confinement of the most disturbed in cellars and the use of baths in their management. There is no direct evidence of hot or cold baths being used for any individual patients, but in 1797 the Master was held responsible for "properly preparing the Bath and bathing of the patients when ordered by the physicians" ${ }^{55}$ Bathing was thus a recognized part of the management of patients at the Bethel.

At the same time as this expansion and improvement in the house's accommodation

\footnotetext{
${ }^{48}$ The fees at St Luke's Hospital were $5 s$ per week in 1789 (quarterly account reproduced in Hunter and MacAlpine, op. cit., note 9 above, p. 515). Thomas Arnold, physician to the Leicester Asylum and the owner of a private mad-house, advertised reduced terms of $8 \mathrm{~s}$ per week and offered to admit two patients free of charge (Peter K. Carpenter, 'Thomas Arnold: a provincial psychiatrist in Georgian England', Med. Hist., 1989, 33: 199-216). See also note 46 above concerning the Manchester Lunatic Asylum.

${ }^{49}$ Lunatics admitted at the request of the Guardians of the Poor (see note 18 above) were to be received at a weekly rate of $3 s$, reduced to $2 s 6 d$ if they were provided with their own bedding (minute of 9 January 1729).

50 The number of patients "on the Foundation" was noted for the first time on 2 January 1764.

${ }^{51}$ See Bateman and Rye, op. cit., note 9 above. Much of the original eighteenth-century building still stands between Bethel Street and Theatre Street in the centre of Norwich despite being well hidden by nineteenth- and twentieth-century additions.

52 Minutes of 21 April 1727, "that there be Six Wards more made ready as soon as conveniently may be", and 26 June 1727, "sills of the roof are very much decayed . . . and at the same time there be another ward at the East end".

${ }_{53}^{53}$ Minute of 1 June 1747.

${ }^{54}$ Minute of 8 May 1749.

55 First of the Rules and Orders of Bethel in Norwich (referred to in notes as Rules and Orders), dated 11 December 1797 (NRO BH24).
} 


\section{The Bethel at Norwich}

references to the "new building" began to appear in the minutes. ${ }^{56}$ In the mid-1750s a new committee room was completed and furnished, and was hung with portraits by Heins of the current trustees. The development of the house reflected new prosperity and confidence, and provided increased capacity for patients. This was prospective development. There is no hint in the early minutes of overcrowding, as there would be later. The number of residents remained stable between twenty and thirty until 1750 . There was then a steady increase which continued throughout the decade. By 1760 numbers had risen to almost fifty. This was not reflected in a similar growth in the population of Norwich. ${ }^{57}$ In 1740 the Bethel housed around 7 residents per 10,000 of the population on average; by 1752 this had increased to 9 per 10,000 , and by 1770 to 12 per 10,000 . The number of individuals that had entered the Bethel as patients represented a greater proportion of the local population. Regular income from fees followed these changes closely; average annual income usually remained over $£ 8$ per head until the 1780 s. Furthermore, the annual accounts reveal a continuous surplus of income above costs over this period, which in every respect was one of growth: patients, income, building, profit. The Bethel's prosperity reflected that of the whole country during the mid-eighteenth century, so much so that in October 1763 the committee felt that "the annual income [was] sufficiently increased... to support all the poor lunatics [of Norwich] upon the Foundation". 58

This boom was as temporary in Norwich, however, as elsewhere. By March 1766 admissions had to be restricted to those from Norwich, Norfolk or Suffolk, an indication that the Bethel had previously received patients from further afield. ${ }^{59}$ Six months later the trustees ordered that there were to be no admissions "without enquiring of the Master as to a vacancy". ${ }^{60}$ In December 1770 the Master was instructed to keep a minute book of applications for admission. ${ }^{61}$ By the 1780s the Bethel was shrinking. Numbers dropped from between forty and fifty resident before 1780 to little more than thirty in the early 1790s. In 1786 the Bethel housed only 8 patients per 10,000 of the population, a similar proportion to that in the 1740 s and 1750 s. This drop in numbers was accompanied by a drop in income, which in the last two decades of the century usually averaged below $£ 8$ per head per annum. Expenses remained steady and then increased by almost twofold in the last years of the century in line with inflation. Ironically, these financial problems were probably compounded by the presence of Foundation patients, whom the trust had been intended to serve. Numbers of Foundation patients were recorded monthly from 1764, the peak of the boom, and they show an initial decline. The first figure noted is twenty-two (44 per cent of the residents) in 1764; five years later this had dropped to between ten and

\footnotetext{
${ }^{56}$ Minutes of 28 May and 20 August 1750.

${ }^{57}$ See census and enumeration data and population estimates tabulated in J. K. Edwards, 'Norwich Bills of Mortality', Yorks. Bull. econ. soc. Res., 1969, 21: 94-113.

58 Minute of 3 October 1763.

${ }^{59}$ Minute of 3 March 1766. Place names were recorded for twenty-one patients up to 1766 and a further twenty-five up to 1813. One patient was recorded as having come from Langley, near Saffron Walden, in 1763 , and another from Wisbech in 1813. Otherwise all recorded place names were located in Norfolk or Suffolk.

${ }^{60}$ Minute of 1 September 1766.

${ }^{61}$ Minute of 3 December 1770. The first of these admission registers have not survived; the earliest that exist are two volumes extensively damaged by water. The legible entries in "Dr Reeve's Register" (NRO BH77) date from 1785, and in "Dr Wright's Register" (NRO BH78) from 1790. Many entries are absent or illegible due to damage. Intact admission registers survive from 1814 on.
} 


\section{Mark Winston}

twelve (23 per cent). Yet as overall numbers dropped in the 1780 s there was a modest increase in charity patients, such that by the 1790s half the resident patients were "on the house". The governors were faced by a combination of problems. The trust was catering for an increasing proportion of patients who paid no fees but represented a drain on its resources at a time of general inflation. Residents with increasing lengths of stay and diminishing chances of recovery probably compounded the problem of the charity patients. In 1783, after losses in seven successive years, the governors acted to restrict the length of stay to two years. They ruled that patients should be "discharged at the end of Two Years from the Entrance unless other wise ordered by the Governors or whenever the Physician shall Certify them cured or not likely to receive any further benefit in this Hospital". ${ }^{62}$ In 1789 the governors were enjoined not to make "any publick or private return with regard to the number of Lunatics admitted ...".63 The crude recovery rate, calculated from entries in the minutes as the proportion of the total number discharged who were classified as "recovered", had been as high as 70 per cent in the 1750 s. By the end of the 1770s it had dropped to below 60 per cent, despite a steady rate of discharge. This and declining numbers may have given the governors cause for concern. Lunatic hospitals and madhouses advertised their success at cure to attract trade and make money. It is possible that an increasingly chronic population with a diminishing recovery rate led to decreased admissions, dwindling numbers, and reduced income.

The response was to expand. In 1791, the committee decided to add eight more beds. ${ }^{64}$ There was a clear and dramatic doubling of numbers over the next fifteen years, from a minimum of thirty-one in 1793 to sixty-five in 1806. The proportion of non-paying residents dropped from more than 40 per cent to less than 20 per cent over the same period, and income rose rapidly, helped after 1801 by the one-third increase in fees. ${ }^{65}$ Between 1785 and 1800 the recovery rate rose to between 70 and 80 per cent of discharges, but it subsequently fell again to less than 60 per cent between 1800 and 1810. In March 1806, after considering the possibility of building a second establishment for male patients, the governors decided that the Bethel should be enlarged to accommodate officially forty male and twenty female patients, ${ }^{66}$ despite the fact that numbers had been more than sixty since December 1805 . This total of sixty patients was to include twenty on reduced fees and twenty on the Foundation, a position the governors felt confident that they could maintain. Despite this new provision, numbers rarely dropped below sixty over the next thirty years; they reached a peak of over eighty patients for a brief period in 1810 and on several occasions thereafter. This policy of relentless expansion resulted in the Bethel once again catering for an ever-increasing proportion of the local population. Over the first decade of the nineteenth century the Bethel housed from 12 to more than 17 patients per 10,000 with a brief peak of 21 per 10,000 .

There were other indications of overcrowding at the Bethel. In 1794, the committee considered the need for "greater accommodation" for female patients, but three years later

\footnotetext{
62 Minute of 7 April 1783. At St Luke's Hospital the limit on the length of stay was one year, although there was a facility for re-admitting a small number of incurable patients after their discharge (French, op. cit., note 32 above, p. 16).

${ }^{63}$ Minutes of 2 February and 7 September 1789.

${ }^{64}$ Minute of 7 March 1791.

${ }^{6.5}$ See note 47 above.

(6) Minute of 19 March 1806.
} 
women were still being housed in a cellar on the male side ${ }^{67}$ In 1809 the minutes recorded a bill of $16 s$ paid to the editor of the Bury paper for two weeks advertising to the effect that "this Hospital on account of the very large nos. of patients therein cannot at that time receive any more", 68

\section{DOMESTIC STAFF AND THEIR CHARGES}

The staff appointed by the committee can be broadly divided into domestic and medical. Mary Chapman had appointed a lay Master to oversee the house at least five years before her death. The Master was never medically qualified. In contrast to the situation in larger institutions and in general hospitals the physicians and apothecaries to the Bethel were employed separately. Details of other domestic staff are not clear until 1753 when an itemized bill for staff salaries was recorded. In the 1740s the total expenditure on "Master and servants" was $£ 12$ a quarter. In 1753 there is the first detailed record of "a Master, a Manservant and two Maids", at a quarterly cost of $£ 1215 \mathrm{~s} ;{ }^{69}$ the manservant was paid $£ 115 s$ a quarter. In 1764 the minutes record a payment of $£ 2$ to the "manservants". By 1809 the quarterly listing of staff salaries included those of the Master, a manservant, two maids, and an indeterminate number of "boys"; three years later the list again refers to manservants. ${ }^{70}$ The fact that no reference was made to the Mistress did not indicate her absence. While it was the Master who was appointed and paid a salary, the Master's wife usually assumed the role of Mistress. It appears that a Master, Mistress, and two maids were generally employed, together with one or two adult male staff. Assuming a total of five adult staff in 1753, six in 1764 and at least seven in 1812, it appears that the patient/staff ratio increased slowly from approximately 6:1 (1753) through 8:1 (1764) to more than 9:1 (1812). Total quarterly salaries increased over the same period from $£ 1215 \mathrm{~s}$ through $£ 147 s$ to $£ 2110 s$. This situation was broadly comparable to that at contemporary St Luke's. ${ }^{71}$

This later rise in staff costs was due largely to the Master's salary which was increased in 1807 to $£ 60$ as a result of "the increas'd number of patients that have been in this Hospital for some years past". ${ }^{72}$ The term "Keeper" was in use in 1783, and appears to have been a general term for the post of Master rather than a reference to male attendants as was the case in many other institutions. However, records of appointments or salaries refer to the "Master". Only once were a Master and Mistress appointed separately. In 1779, the Master, Thomas Doyne, died after three years in the post. He was replaced by

\footnotetext{
${ }^{67}$ Minutes of 5 July 1794 and 7 July 1797.

${ }^{68}$ Minute of 2 October 1809.

${ }^{69}$ Minute of 9 April 1753.

${ }^{70}$ At St Luke's Hospital in the 1750s the Keeper and his wife were assisted in caring for up to seventy patients by two male and two female attendants; the latter received $£ 10$ a year each, somewhat less than the salary at the Bethel, and a gratuity of $£ 4$ each (French, op. cit., note 32 above, p. 20). In 1781-2 the staff at the Norfolk and Norwich Hospital included an apothecary (salary $£ 50$ per year), a matron (salary $£ 15$ with gratuities of $£ 10$ ) and a cook, a maid, a porter, an errand boy, and a number of nurses and attendants (total salaries $£ 2614 s 7 d$ ), (editorial, Pharmaceutical Journal, 1954, 4th Series, p. 263). At the Royal Salop Infirmary the apothecary and matron were considered "the Master and Mistress of this House" (see Howic, op. cit., note 32 above, p. 45).

71 In 1789 fifteen staff were employed at St Luke's apart from the Master and Matron. Before 1789 the staff bill amounted to $£ 46$, or $£ 214 s$ per head, and after this date to $£ 61$, or $£ 312$ ser head (see French, op. cit., note 32 above, pp. 33-4). The approximate equivalent staff costs at the Bethel were $£ 217 \mathrm{~s}$ in 1764 and $£ 312 \mathrm{~s}$ in 1812 .

${ }^{72}$ Minute of 5 October 1807.
} 


\section{Mark Winston}

Robert Waller, and his widow, Mrs Doyne, was formally appointed as Mistress. They each received $£ 20$ annually. ${ }^{73}$ In 1791 the widow of John Corsbie, Master, referred to as "the mistress", was granted an annuity of $£ 21$ after his death. ${ }^{74}$ Not all Masters retired gracefully or died peacefully. In 1756 Edward Page was discharged from his post because of his "great Age and Infirmities" and received a pension of $£ 20 ;{ }^{75}$ James Bullard was attacked by one of the patients with a scythe and died of his injuries in March $1813 .^{76}$

Problems with staff arose in June 1725, within months of the trust's beginning. It appears that the Master, Robert Waller, had "at several times lett great numbers of people into the House to the no small disturbance of the Lunaticks, and contrary to the known will and intention of the Trustees, and has also corrected some and managed others of the said Lunaticks in an undue manner...". This misdemeanour was compounded by his using "several contemptuous expressions against the said Trustees declaring that he would not be directed by any man ..." ${ }^{77}$ The trustees had decided views on how the lunatics were to be treated. While they were to be subject to "correction", they were not to be disturbed by visitors, and the trustees were clear in their own minds when the Master overstepped the limits of reasonable correction. They also knew when he had exceeded the legitimate bounds of their authority. The trustees responded in two ways. They reduced Mr Waller's salary by $4 s$ per week and instituted regulations for visiting. No more than twelve visitors could be admitted at one time, and their stay could not exceed fifteen minutes. Visiting was forbidden on Sundays; otherwise it was to be between 9 and 11 a.m. thoughout the year, and between 2 and 5 p.m. (in the summer) or 1 and 4 p.m. (in the winter). ${ }^{78}$ It appears that visitors paid the Master to come and view the house and its residents, and this formed a significant part of Mr Waller's income, for eight months later the committee decided that the "Profits of the Keys [which were to be collected in a locked box] shall from Ladyday next ensuing be at all times applied wholly to the use of the poor Lunaticks ${ }^{79}$ and in consideration thereof the Master shall have his Salary augmented . . ."-by $£ 10$ a year. ${ }^{80} \mathrm{He}$ was to be provided with "meat and drink for himself, his wife and servants"; the trustees also undertook to provide extra staff when necessary and to pay all taxes and parish charges levied on the house or on the Master's private estate. The income from admitting visitors in 1724-5 must have been considerable to justify a salary increase of one third and such a package of fringe benefits. The earliest record of box receipts was $£ 4511 \mathrm{~s} 1 \mathrm{~d}$

\footnotetext{
${ }^{7.3}$ Minute of 1 November 1779. In 1772 an apothecary and a matron were appointed to the Norfolk and Norwich Hospital. They were resident and received $£ 30$ and $£ 15$ per annum respectively.

${ }^{74}$ Minute of 5 December 1791.

75 Minute of 5 July 1756.

${ }^{76}$ Minute of 26 March 1813.

${ }^{77}$ Minute of 28 June 1725.

${ }^{78}$ Visiting at the Royal Salop Infirmary was restricted to Tuesdays and Fridays between 2 and 4 p.m., and banned on Sundays (Howie, op. cit., note 32 above, p. 53). Rule 35 of the original Rules and Orders of St Luke's Hospital stipulated that "the Patients in this Hospital be not exposed to publick view" (quoted in French, op. cit., note 32 above, p. 193).

${ }^{79}$ Consider the similar practice of charitable and casual giving, as well as the infamous (and perhaps mythical) "charge" to visit Bethlem, discussed in Allderidge, op. cit., note 10 above. Under the regulations passed on 27 May 1728 the Master of the Bethel was required to show visitors the box.

${ }^{80}$ The Master's salary was increased to $£ 40$ per annum (minute of 18 February 1725). This was similar to the salary of the head Keepers, a husband and wife, at St Luke's Hospital who received $£ 30$ per annum, with gratuities of $£ 10$ and $£ 6$ each (see French, op. cit., note 32 above, p. 20). However the matron at Westminster Hospital in 1725 received only $£ 12$ per annum (Humble and Hansell, op. cit., see note 32 above, p. 12).
} 


\section{The Bethel at Norwich}

in 1730-2; receipts remained generally above $£ 20$ a year until 1750 and remained greater than $£ 10$ a year until $1770 .{ }^{81}$ The trustees' response suggests a concern for the good management of the house and to stop the exploitation of its residents. Despite this there were to be further problems. In December 1743 there was an unspecified but "just cause of complaint" against Mr Waller and he was given notice till the following Lady Day "if he behaved"; he did not and the following month was given one week's notice. ${ }^{82}$

This was the most protracted incident, but there were other issues and events which concerned the trustees. The minutes briefly and irregularly recorded their worries and decisions, such as the ruling in 1758 that residents were not to be allowed private conversations with their spouses, ${ }^{83}$ or that made in 1761 to the effect that "no provision of meat or drink of any kind sent to the Lunatics in this Hospital shall be received by the Master ... or ... given to the Lunatics without consent of the Trustees". 84 These rulings were not unique and reflected the increasing regulation of institutions during the eighteenth century, not just at the Bethel but at St Luke's and Bethlem as well. The governors were concerned with order and control. In 1778 they stated that "Burials from this Hospital shall be performed in the most private manner and that the Corps be not carried out of the Front Iron Gates". ${ }^{85}$ In 1785 a servant, Stephen Freary, was dismissed for "insolent and intractable behaviour", ${ }^{86}$ reminiscent of Mr Waller's misdemeanour. The final comment relating to staff is a minute from 1797 which first forbade the Master from keeping pigeons or poultry on the site and then cancelled his leave of absence. ${ }^{87}$ The general tone of these entries is domestic and administrative; there is little formal comment on the handling of the residents themselves. The governors instituted a system in $1776^{88}$ under which they took it in turn to visit the Bethel for a two month period. ${ }^{89}$ Sadly, no records exist of the precise purpose and nature of the visits, which do not appear to have been practised before, but the monthly committees had received reports on patient numbers, disbursements, and incidents concerning the lunatics from the Master, and continued to do so.

The earliest surviving Rules and Orders date from $1797 . .^{90}$ There is no formal record of staff management before this. Their formulation appears to have been immediately preceded by the Master's absence from the house and his keeping poultry and pigeons on site. They may have been put in writing as a formal response to problems with staff conduct rather than a sign of newly enlightened concern or policy. A special meeting of

${ }^{81}$ Account Book BHI.

${ }^{82}$ Minute of 9 January 1743.

${ }_{83}^{83}$ Minute of 18 September 1758.

${ }^{84}$ Minute of 9 November 1761. Rule 32 of the Rules of the Norfolk and Norwich Hospital, 1773 (NRO NNH14/1) stipulated similarly that no "Provisions or Liquor" were to be brought in.

${ }^{85}$ Minute of 2 November 1778.

${ }^{86}$ Minute of 3 August 1785.

${ }^{87}$ Minute of 18 November 1797.

8x Minute of 4 March 1776.

${ }^{89}$ The administration of the Royal Salop Infirmary appointed two House Visitors each week from among the contributors. They were obliged to visit daily to ensure good order and that the rules of the charity were being observed (Howie, op. cit., note 32 above, p. 44). House visitors were appointed to the Manchester Hospital and Asylum "to observe the behaviour of the Keeper, Matron and servants ... and in particular the bedding and nightly accommodation..." (D. Leigh, The historical development of British psychiatry, vol. 1, Oxford, Pergamon Press, 1961, p. 13).

${ }^{90}$ Rules and Orders, see note 55 above. 
the governors decided that the constant attendance of the Master was required and defined a number of specific duties. The Master was personally to assist the male patients in getting up and going to bed, to prepare their baths when prescribed, to carve and serve their meals, and to administer medicines "agreeably to the directions of the Physician"; 91 the Matron was similarly responsible for the female patients. ${ }^{92}$ The rules laid down the times for the lunatics to rise and retire. Between Lady Day and Michaelmas they were to get up at seven in the morning and go to bed at six o'clock; in the winter these times were to be "by Daylight" and "by Candle-lighting" respectively. Breakfast was to be "served out immediately, Dinner to be served at 12 o'clock and Supper half an hour before Bed-time". ${ }^{93}$ Patients' hands and faces were to be washed daily and "the Hospital and particularly the Patients Apartments as well as the Person Bed and Bedding of the Patients be kept as well aired sweet and clean as possible..."94 Some of the regulations concerned safety and security; the Master was to check the fires at night and be responsible for the keys, and "Knives, Forks, Scizzars and every kind of Steel or Iron Instruments or Garden Tools, Lines and Ropes when not in use" were to "be carefully and constantly kept from the reach and sight of the Patients...".95

Other regulations hint at exploitation of the Bethel or its patients. Patients were not to be engaged in domestic duties unless adequately supervised, and then only at the physician's direction, and they were not to be sent on errands. ${ }^{96}$ Cards and games of chance were prohibited. Visits were restricted: "no Lunatick [to] be visited by their Friends oftener than twice in a month nor by more than two persons at a time without a Special Order from a Governor or Physician and that not more than six Persons be admitted at the same time to see the House". 97 Rule 15 stated "that the Master and Matron be inform'd and thereby impress'd with a sense of the duty and humanity they owe to the Patients of the House and that in obstinate resistances of the Patients to be governed no blows or correction with any weapon be used but the most gentle and humane means observed and followed to control the obstinate paroxysms of the Patients". This was not necessarily a new policy. Given the earlier concern over undue correction it may be that the committee were merely restating the previous policy. The Rules and Orders also included administrative regulations. The Master and Matron were not to be absent from the Bethel simultaneously, nor were they to use the governors' room without permission. They were not to keep servants other than hospital staff. An updated inventory was to be maintained and presented to the governors when required. ${ }^{98}$

These regulations, formulated at the end of the eighteenth century, find echoes in the Rules and Orders of the General Infirmary at Leeds, ${ }^{99}$ Bethlem, ${ }^{100}$ and the Norfolk and

"Rules and Orders: 1st, 2nd and 4th Rules.

"2 Rules and Orders: 5th Rule.

${ }^{93}$ Rules and Orders: 6th and 7th Rules.

${ }^{94}$ Rules and Orders: 7th and 17th Rules.

"5 Rules and Orders: 2nd, 10th and 16th Rules.

"Rules and Orders: 11 th and 14th Rules.

${ }^{97}$ Rules and Orders: 8th Rule.

${ }^{9 x}$ Rules and Orders: 9th, 12th, 13th, 19th and 20th Rules.

"Q Quoted in Woodward, op. cit., note 19 above, p. 29.

${ }^{100}$ See the excerpts from the minutes of Bethlem quoted in Hunter and MacAlpine, op. cit., note 9 above, pp. 427-9, concerning the risks to patients of knives and other sharp objects, and the servants responsibility to prevent escape. 


\section{The Bethel at Norwich}

Norwich Hospital. ${ }^{101}$ Together with the specific incidents recorded, they reveal a concern for the cleanliness and freshness of the building and its residents, and for the proper observance of an orderly routine. In general voluntary hospitals, the staff "were employed not as medical attendants but as servants" and the duties of the Matron were "those of a housekeeper"; ${ }^{102}$ at the Bethel they were never honoured with the title of nurse during the eighteenth century. As well as good order, the patients' safety was also of concern; they were to be protected variously against exploitation, fire, self-injury or assault, excessive physical restraint, and escape itself. The Rules and Orders reflect a humane attitude to the mad but a strongly authoritarian humanity it was, for both staff and patients. This demonstration of concern in 1797 needs to be compared with other available evidence on the management of the patients. It was the custom at the Bethel to record an inventory of the house on the appointment of a new Master. That of 1743, when there were twenty-five residents on average, included five pairs of handcuffs, ten padlocks, and two chairs and staples; ${ }^{103}$ in 1776 there were ten chains and twenty handcuffs, and forty-five lunatics. ${ }^{104}$ A heavy chair with holes for straps or chains still remains in the Bethel Hospital. Three strait waistcoats for "disorderly lunatics" were ordered in 1758 and a further six in

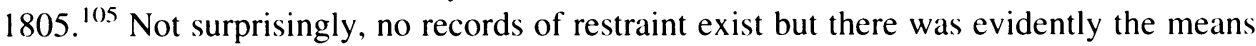
available to restrain a large proportion of the residents at any one time, and it seems unlikely that the trustees or governors would have countenanced purchasing equipment that was not deemed necessary or likely to be put to use. While they acknowledged a humanitarian and charitable duty to those housed at the Bethel, it is clear that the trustees and governors accepted the need for, and the use of, restraint as part of accepted therapeutic wisdom of the eighteenth century.

\section{MEDICAL STAFF AND THEIR PATIENTS}

The trustees appointed medical staff to the Bethel from the very beginning. The senior medical staff were physicians, initially one and later two, retained on an annual salary. They were responsible for the admission and discharge of patients and for the prescription of treatments, but there is no surviving evidence that they were required to visit the hospital or their patients on a frequent basis. The committee also retained a series of apothecary surgeons, although in contrast with other larger institutions, they were never resident. Responsibility for the daily management of the patients lay with the Master and his domestic staff, who also had a role in the administration of treatment. The apothecaries provided medications both to the house and for specific patients. They did not receive a salary, but tendered yearly or twice yearly bills for their services. They also provided some medical care to the domestic staff, and charged the committee for this. In the year 1795-6 the manservants received between them an emetic, two purges and a bleeding; the

\footnotetext{
101 The Rules of the Norfolk and Norwich Hospital, 1773 (NRO NNH 14/1), were also concerned with domestic security and order (Rules 71 to 89). Rule 79 expressly instructed that "the Nurses and Servants obey the Matron, as their Mistress, and that they behave with Tenderness to the Patients...".

102 Woodward, op. cit., note 19 above, p. 29.

${ }^{10.3}$ Minute book NRO BH 16 .

${ }^{104}$ Minute book NRO BH11.

105 Minutes of 24 July 1758 and 1 January 1805.
} 
maidservants received an emetic, a liniment, two doses of alterative drops and one had a tooth extracted. ${ }^{106}$

The Bethel was served by three successive apothecaries or apothecary surgeons between 1724 and 1828 but little information exists in the archive concerning their practice. ${ }^{107}$ There is nothing in the minutes to indicate their duties or responsibilities, but they do contain records of the apothecaries' accounts. It was the apothecaries who presented bills for the costs of medical treatment although they had a less formal status than the physicians. The first record is that of a bill from Thomas Johnson, presented for payment in $1727 .{ }^{108}$ It was minuted along with those of other tradesmen: a carpenter, a plumber, and a glazier. Thomas Johnson retired in 1748. In 1750 his successor Abel Meen was paid for "physick and surgery", and the following year for "surgeon's business and medicines". ${ }^{109}$ From 1727 annual or twice yearly bills were received and noted. The apothecaries seem to have been busy either dispensing or administering treatments. In the year 1795-6 James Keymer provided 381 separate treatments to forty-three patients on 199 separate occasions. ${ }^{110}$ The average number resident over this same period was forty and the minutes record twenty-five discharged patients. The majority of these received some form of medical treatment at increasing cost. There had been a clear but erratic increase in the apothecaries' prices since 1730. The annual account rose above $£ 10$ in 1741 , above $£ 20$ in 1762 , and above $£ 30$ in 1774. In 1783 the apothecary's account amounted to $£ 4119 \mathrm{~s}$, the first and only time it was more than $£ 40$. This peak appears more dramatic when costs are adjusted for the average number resident. From 1740 to 1780 average apothecaries' costs were rarely more than $12 s$, and never more than $16 s$ per head. In 1782-3, at the beginning of the slump more than $20 s$ was spent for each patient resident. The minutes at the end of that financial year included a brief request that Dr Manning prescribe the nitre provided by the house ${ }^{111}$ the costs of his prescriptions were regularly much greater than those of his fellow physician, Dr Beevor.

Sir Benjamin Wrench, was made a trustee at the first meeting of the committee. Just over two months later he was the first physician to be appointed and it was decided soon after that his salary should be $£ 16$ per annum. He was a Cambridge graduate and had practised in Norwich for approximately thirty years before his appointment at the age of fifty-nine. Little is known about him and even less about the men and women under his care at the Bethel. ${ }^{1 / 2}$ No formal record remains of the residents at the time. The number

\footnotetext{
${ }^{106}$ In the year 1795-6 the apothecary provided the house with peppermint water, friars balsam, chamomile flowers, spirits of hartshorn, cerate, spirits of wine, yellow balsam and purging salts. These were not provided for named patients (apothecary's accounts, NRO BHII70 and BHII71).

117 Thomas Johnson (up to 1748), Abel Meen (1748-1773) and James Keymer (1773-1828).

${ }^{108}$ Minute of 30 May 1727.

${ }^{109}$ Minutes of 15 October 1750, and 9 December 1751.

110 The original apothecary's accounts itemizing each physician's prescriptions for the year 1795-6 still survive (see note 106 above).

'1' Minute of 7 April 1783.

112 See C. Williams, Norfolk Chronicle, 11 November 1899. He was born in 1665 and graduated BA from Caius College, Cambridge, in 1684; he gained his MD in 1694 and returned to practise in Norwich. His elder brother was a worsted weaver and his younger brother was vicar of Aylsham, a nearby town. He and his brother subscribed to a volume entitled An essay on hot and cold bathing by Jonathan King, apothecary, published in London in 1737. He held the post of physician for almost twenty-two years and remitted his salary for this period to the charity. Within a year of his retirement he had died. His son-in-law, Wharton Peck LLD, was appointed a trustee after his retirement.
} 
varied between twenty and thirty. There are nine references in the minutes to individuals being admitted "on the Foundation" during his twenty-three year tenure, but no other information on the lunatics. Although this silence suggests a predominantly administrative interest in the residents, it does not necessarily imply a lesser degree of clinical interest than would have been expected at the time. Indeed, Sir Benjamin's subscription to a volume on bathing by a London apothecary suggests an active interest in his profession. Records were kept for local use and the Bethel's primary task was to care for, and maintain, pauper lunatics. This concern for the welfare of lunatics was increasingly a part of social awareness but the medical profession had yet to claim a specific interest and expertise in the mad. For this reason, how and why residents came and went was not worthy of note, but if they came to incur a charge on the trust this was duly minuted, Further, it is unlikely that only nine patients were maintained on the trust over this time. The recorded cases must have been of particular note. Some had suffered for long periods. For example, John Flegg sought the admission of his son, "a Lunatick ... for many Years". ${ }^{13}$ Isaac Lewis sought the admission of his brother, Philip, who had "been so long disordered in his Senses for near five Years ..." that he was unable to maintain him. ${ }^{114}$ Patient numbers were recorded monthly from 1730 and the figures indicate that even at this early period there was a high rate of patient movement. Over the first twenty years at least 120 individuals were admitted, the equivalent in one year of one admission for every four individuals resident. ${ }^{115}$

Sir Benjamin retired on 19 January 1747 aged eighty-two. He informed the trustees that "the Season of the year and my own advanced age rendering it difficult for me to visit at Bethel as usual; and having now fully performed my promise to Mrs Chapman in attending as physician as long as I was able, I send this to desire you to provide some other person, proper to succeed me; and till then I shall readily give my assistance upon any occasion that may require it. I am Gentlemen your most obliged and humble servant Benjamin Wrench". ${ }^{116}$ Dr Kervin Wright was appointed a week later. ${ }^{17}$ A graduate of Aberdeen, he remained on the staff of the Bethel until 1758. Numbers of residents began to rise soon after Dr Wright's appointment, reaching thirty for the first time in 1750, and forty in 1755 . The period of his appointment was also characterized by a change in the way patients were referred to in the minutes. In 1750, for the first time, more than one name was recorded in them in one year. By 1753 six of the ten patients mentioned were noted as being discharged. Eight were referred to as "lunatics", a term that would be used of the majority of the patients over the remainder of the century. In the same year the minutes record the first description of a patient who was said to have "recovered", the first of a number of clinical categories introduced over the next fifty years. This was the beginning of a significant shift in emphasis, from admission to discharge, from financial administration to clinical description.

\footnotetext{
11.3 Minute of 18 August 1729.

114 Minute of 10 January 1725 .

115 This estimate is calculated from the numbers recorded in the Bethel on a monthly basis. Admissions totalled 121. This does not allow for the fact that patients may well have been admitted and discharged at the same time, and this figure is necessarily a low estimate.

116 Minute of 12 January 1746.

117 See entry in W. Munk, Roll of the Royal College of Physicians of London . ., vol. 2. 1701-1800, London. Royal College of Physicians, 1878 (Munk's Roll), p. 150. Born in 1720, he had trained at Aberdeen, from where
} 


\section{Mark Winston}

Dr Wright retired in July 1758, "he being in some measure rendered incapable by the Loss of his Sight". ${ }^{118}$ The trustees took the decision, unusual for an institution of less than forty patients, to appoint two physicians, John Beevor and John Manning. At thirty-three Dr Beevor was the older by five years. ${ }^{119}$ His colleague, Dr Manning, had trained at Leiden between 1753 and 1756. ${ }^{120}$ They had an effective "partnership" in other medical ventures. Both men were appointed together as physicians to the Norfolk and Norwich Hospital, before it was opened to patients in 1772. ${ }^{121}$ Dr Beevor also had an interest in a private mad-house at Lakenham, now a suburb of Norwich, in company with one Joseph Hill, to which Dr Manning was appointed visiting physician under the legislation of $1774 .^{122}$ It is not clear from the records why the trustees chose to appoint two physicians. Although they practised in similar settings, they worked independently at the Bethel and had their own individual patients; their prescribing habits and costs were very different. ${ }^{123}$ Their appointment followed the first period of building development and a rapid and continued increase in the numbers of residents noted above. It may have been that the trustees were planning a further increase. If so, this was only partially fulfilled. Beevor and Manning remained on the staff for half a century, a period which saw initial expansion, recession, and a further period of growth. Dr Manning did not retire from his post until 1805; Dr Beevor retired three years later.

The minutes of the last half of the eighteenth century provide the most detailed information about the patients. More than half those referred to were women, and at some periods two thirds. This held in relation to all records, all discharges $(61$ per cent of the total), and those discharged as recovered (61 per cent). There was a tendency for women to form an increasing proportion of the record in the last decade of the eighteenth century and the first fifteen years of the nineteenth. By 1806 the governors perceived there to be a need for beds for twice as many male as female patients. ${ }^{124}$ The fact that twice as many female patients were being discharged while space was needed for male patients suggests that men contributed to the chronic population while women predominated in the acute, or recurring, population. ${ }^{125}$ The minutes contain almost 1,300 records of named patients which refer to approximately 900 individuals; the majority of records refer to discharge. There are 142 separate names recorded as having been discharged more than once. This

he gained his MD in 1744. He was admitted as an extra-licentiate of the Royal College of Physicians on 17 September in the same year and returned to practise in Norwich.

${ }^{11 \times}$ Minute of 24 July 1758.

119 See P. J. Wallis and R. V. Wallis, Eighteenth century medics (subscriptions, licences and apprenticeships), Newcastle-upon-Tyne, Project for Historical Biobibliography, 1985, p. 81 . He gained his MB in 1748 and his MD at Cambridge in 1764. He later served the city as Deputy Governor of the Corporation of Guardians of the Poor, see note 18 above.

${ }^{120}$ See Munk's Roll, op. cit., note 117 above, p. 212-13. He was admitted as an extra-licentiate of the Royal College of Physicians in 1757 and settled in Norwich.

121 Minute Book NRO NNH1/1. They were both appointed on 15 January 1771.

122 The first licence for this house was granted on 20 November 1774 (Quarter Sessions Minute Book, NCR Case 20, Shelf a, No. 22).

${ }^{12.3}$ Separate accounts were recorded for each physician's patients over a seven-year period from 1779 to 1796 . Dr Manning's treatments consistently cost twice that of his colleague's, despite having similar numbers of patients under his care (Dr Manning: $£ 14613 s 6 d$; Dr Beevor: $£ 6518 s$ ), and he used a greater variety of preparations per patient. Both used a wide range of treatments but there was little common prescribing (NRO BH1, BH1170), BHI171).

124 Minute of 19 May 1806.

${ }^{125}$ See Turner, op. cit., note 2 above. He shows that male patients tended to have longer admissions. 


\section{The Bethel at Norwich}

group ( 16 per cent of the patients) accounted for 33 per cent of all discharges. ${ }^{126}$ Of those repeatedly discharged, 66 per cent were female; this is similar to the proportion in the group of patients discharged just once. The majority of these patients were recorded as discharged on just two occasions, but a few had heroic careers. "James Cook"127 was discharged on twelve occasions between 1770 and 1789; "Thomas Fenn" left the Bethel eight times between 1778 and 1792. "Mary Baxter" was discharged seven times from 1795 to 1808. The apothecary's account for the year 1795-6 reveals that she received a well-regulated regimen. ${ }^{128}$ She was given two purges in mid-August four days apart. A third purge was administered on 1 September before she received a further series of medicaments. Powders were given on seven occasions at four-day intervals and a fourth purge was administered at the midpoint of this course. The last dose was given on 30 September and she was discharged for the first time on 5 October.

Discharge was not always an administratively simple affair. In 150 cases other individuals or officials were involved in the process of discharge. Friends sought the discharge of the patient in almost half of these cases. Two thirds of these patients were women, of whom 40 per cent had either recovered (the majority) or had benefited from admission; men fared worse. In fifty-eight cases family members or relatives were involved. In the case of female patients, this was almost exclusively the husband, and the ultimate result was very different. Only 20 per cent of these women had a good outcome, and only one was said to have recovered. ${ }^{129}$ Family members sought the discharge of male patients on only twelve occasions; in two thirds of cases a parent, brother or sister applied. A third of this group had good outcomes. The others who applied for patient discharge were parish overseers or workhouse officials. Thirteen women and eleven men were discharged into their care. The prospects for this group were uniformly poor; only 25 per cent had a good outcome recorded.

As the century progressed, the minutes of the Bethel noted an increasing number of physical problems. Such complaints were recorded as early as 1754 when the friends of Leonard Wizeard were ordered to pay for surgery. ${ }^{130}$ While not common, surgical problems were those most frequently recorded up to 1781 . In 1774, two years after the opening of the Norfolk and Norwich Hospital, the governors ordered that cases of surgery should be reported to them. ${ }^{131}$ In 1781 , they directed more particularly that in "any surgery case...the apothecary and surgeon do give immediate Notice thereof to the Clerk ... who is hereby directed by Letter to give notice thereof to the Securitys of such patients". ${ }^{132}$ Such cases were still to be reported to the Board of Governors and no payments were to be demanded without the Board's consent. The last recorded case of surgery was entered in the same year, when the surgeon received $£ 1114 s 6 d$ for treating Lydia Claydon, "late a lunatic", the overseers of Wells paying half the costs. ${ }^{133}$ During the

\footnotetext{
126 This readmission rate was similar to that reported at Bethlem (Andrews, op. cit., note 6 above, p. 71).

127 The use of inverted commas indicates that, while the name James Cook appeared twelve times in the minutes, it cannot be certain that it referred to the same individual on each occasion.

${ }_{128}$ Details from apothecary's accounts for year 1795-6, see note 106 above.

${ }^{129} \mathrm{~A}$ good outcome is taken to be one of recorded recovery or apparent benefit.

${ }^{130}$ Minute of 11 February 1754.

1.31 Minute of 7 February 1774.

132 Minute of 2 April 1781.

${ }^{1.33}$ Minute of 7 May 1781.
} 


\section{Mark Winston}

last two decades of the eighteenth century and into the nineteenth, medical problems were recorded more frequently. The first description of a resident as "unfit" on discharge appeared in the minutes in 1774 , although the term was not used with any regularity until 1800. It tended to be associated with physical disorder rather than mental disturbance. Fifteen of the fifty-four patients discharged as "unfit" between 1774 and 1813 had a physical problem noted; seven of these had general infirmity. Only three of the "unfit" patients were recorded as being "incurable", "in a state of idiocy" and suffering with "idiotism" respectively. In contrast, the term "unfit" was used of only fifteen of the forty discharged patients with a record of a physical problem. Eight of these were said to have had one or more fits, six women were pregnant or, in one case, showed "symptoms of being pregnant", and three suffered with "paralysis". Other complaints were smallpox, fever, rheumatics, and "the greatest degree of deafness", all of which were noted once each. In twelve cases with medical problems recorded, no outcome status was given, while four were noted to have received some benefit while at the Bethel. Five of this group with physical complaints were described as "improper" patients; this term was used only sixteen times during the entire period of this study.

From the 1750 s the outcomes of individual cases were more frequently minuted. The first category to be recorded was that of "recovered" which, although not defined, had a positive suggestion of restoration and cure. In an institution devoted to the care of the disturbed, recovery must have been both a striking event in itself and an indication to discharge the person under the terms of Mary Chapman's will. Unlike some institutions, the trustees of the Bethel did not require patients to attend on them in order to express their gratitude for the restoration of their senses, either to themselves or to God, or if they did, it was never recorded. The term "recovered" was used from the time, in 1753, when patient records began to appear with significant frequency. By the end of the decade "incurable" and "improper" had entered the record but, like the description "unfit", these were infrequently used. By 1764 an intermediate category of "not likely to receive any further benefit" appeared, a term similar to that in use at St Luke's and, later, at the Norfolk and Norwich Hospital. This was used for 107 discharged patients, most frequently between 1770 and the mid-1780s. It was not applied to one sex more than the other. Not until 1782 did a more positive intermediate category emerge, variously described as "relieved", "received benefit", or "much recovered". Thus, the evolution of outcome categories moved from awareness of lunatics' recovery to recognition of those with unchanging disturbance and little chance of future change and, finally, to acknowledgement that some received modest or incomplete benefit from their stay in the Bethel.

From 1789 the minutes began to record the name of the physician responsible for each patient at the time of discharge. The term "patient" first appeared in the minutes in 1800, at the same time as deaths were first recorded. The records of individual patients gave increased details of both management and results. The progressive medicalization of the records, with the noting of physical disease, the responsible physician, the new status of "patient", and the recording of deaths, echoes the changes in the medical profession and its practice, and in the perception of the appropriate place for sick individuals during the eighteenth century. The character of hospitals as medically-orientated institutions also altered, as did the relationship between physician and patient; the physician gained a 


\section{The Bethel at Norwich}

position of professional authority and the patient became increasingly an object for observation and classification. The opening of the Norfolk and Norwich Hospital in 1772 was an important event, and both a product of the changing practice of medicine and a potential stimulus to further local change. At the time of its opening the recording of clinical details in the minutes of the Bethel was still minimal, restricted in the main to listing the outcome at discharge and sometimes the physician responsible for patients' care. Many entries were administrative and involved financial matters: bills for the house, communications with families or parish officials about unpaid fees or treatment costs, and requests for the physicians to limit their prescribing. By the early nineteenth century the entries had changed to reflect a new view of patients and their place in the Bethel. A new medical element entered the record alongside the established administrative one.

In 1805 Dr Manning was replaced by Dr Richard Lubbock. ${ }^{134}$ Dr Beevor retired in 1808 and Dr Lubbock died suddenly in the same year. The trustees again appointed two physicians. Dr Warner Wright was a Norwich man who had trained at Edinburgh before returning to practise in his home city. Like his predecessors, he was appointed to the Norfolk and Norwich Hospital, where he remained until 1840, but served the Bethel for a further five years. He was instrumental in setting up the Norwich Dispensary, and was also appointed to the new county asylum at Thorpe St Andrew. ${ }^{135}$ His colleague, Dr Henry Reeve, was another Edinburgh graduate; ${ }^{136}$ his tenure at the Bethel was ended by his premature death in 1814 . The governors chose not to replace him, but to continue with a single physician, unless "it shall be found from experience that the Medical Duties of this Hospital are such as to require the appointment of a second Physician". ${ }^{137}$ Perhaps the opening of the county asylum at Thorpe St Andrew seemed to offer alternative facilities for some of the paupers at the Bethel and the need for medical care was thus expected to be reduced. The new asylum certainly gave the governors an opportunity to discharge a number of their patients; notice was given to the parishes concerned, who promptly arranged their admission to the county asylum. For the next three decades, until the Lunatics Act of 1845, the number of patients at the Bethel remained between seventy and eighty, while those in the new asylum increased, as in all such institutions, from 73 in 1816, to 174 in 1845 (and 330 in 1860). Interestingly, while the overall numbers at the Bethel remained level, the proportion of those on the Foundation steadily increased from less than a third in 1815 to more than half in 1845 . In any event, a second physician was appointed only when the legislation in 1845 made the appointment of a Resident Medical Officer mandatory. Three other events are of interest, although they occurred outside the strict temporal scope of this paper. They relate to visits to the Bethel made by Joseph John Gurney in his capacity as visiting governor. In September 1828 he visited the hospital with

\footnotetext{
${ }^{1.34}$ See Wallis and Wallis, op. cit., note 119 above. He had gained his MD at Edinburgh in 1784 and had been apprenticed to Dr Edward Rigby at the Norfolk and Norwich Hospital before gaining his own appointment there in 1790.

1.35 See Munk's Roll, op. cit., note 117 above, vol. 3, 1801-1825, p. 51.

${ }^{1.36}$ See Munk's Roll, op. cit., note 117 above, vol. 3, 180I-1825, p. 46, and Dictionary of national biography, London, Smith, Elder, 1908-9, 22 vols, vol. 16, p. 849. He started his medical apprenticeship in Norwich at the age of sixteen. After qualifying in 1803, he worked at the Public Dispensary in London before returning to Norwich. In 1802 he published a paper on Pinel's article 'Treatment of the insane' in the Edinburgh Review. ${ }^{137}$ Minute of 5 December 1814.
} 


\section{Mark Winston}

his sister, Elizabeth Fry. ${ }^{138}$ Two days later a Middlesex magistrate visited and pronounced himself "much pleased" with his visit. ${ }^{139}$ Finally, in June 1830, William J. Tuke accompanied Gurney to the house and suggested that the galleries might be opened up to provide a variety of exercise for the patients. ${ }^{140}$

\section{CONCLUSIONS}

In this paper I have tried to outline the organization and activity of the Bethel during the eighteenth century and up to the nineteenth century. Relatively little has been written about the details of management and practice within eighteenth-century lunatic hospitals. The Bethel began as a personal and largely unrecorded foundation, built and maintained on the energy and endowment of a particular individual. After Mary Chapman's death, her will transformed this private institution into a public trust managed by committee and constrained by specific directives within that will. The committee set about developing the Bethel to accommodate increasing numbers of residents and employed staff to undertake this. These included physicians, apothecaries, and domestic staff within the Bethel. From an early stage, they developed their own form of certification and laid down regulations for the management of the institution and its inmates.

Like its larger contemporary, Bethlem, the Bethel has gained an undeserved reputation. It has been said that the Bethel never "assumed any national importance". ${ }^{141}$ Certainly, none of its medical staff is known to have published works with wide circulation, nor were they involved in the wider political and professional processes of the eighteenth century. However, the absence of these limited criteria does not necessarily diminish the Bethel's significance. The Bethel was the product of local wealth, position, politics, and religion. It was an important institution in eighteenth-century Norwich. Although small in absolute numbers, it received large gifts and was served by leading figures in local political life. Neither of these suggests a small forgotten charity. The dynamics of eighteenth-century society demanded a return on investment of time, money or position; those dissenters in religion also required devotion to good works. Rather than standing as an outdated relic of a previous era of charity and care, the Bethel offers a view of the development of "proto-psychiatry" outside the capital during the eighteenth century. The first century of the Bethel's existence spanned a period of social, political, and medical change. The Bethel began to care for the mad more than twenty-five years before St Luke's Hospital and without the experiences of a local general hospital as a model. In its establishment, staffing, and early administration it resembled other local institutions. It was founded to contain and care for those suffering in their minds, but, from the first, it was expected to effect the restoration of sanity. The Bethel did not develop idiosyncratically but evolved into a medical institution similar to many others, in particular after the local general hospital was established. It also experienced similar economic and clinical problems to other institutions for the mentally ill, both contemporary and later. In short, some patients neither recovered nor paid their way. The process of expansion to assume responsibility for ever-increasing numbers of patients, both in absolute terms and relative to the local

\footnotetext{
${ }_{1.38}$ Visit recorded in the Visitors Book 1828-1850, BH25, 12 September 1828.

1.39 Visitors Book 1828-1850, BH25, 14 September 1828.

140) Visitors Book 1828-1850, BH25, 17 June 1830.

$1+1$ Porter, op. cit., note 3 above, p. 130.
} 


\section{The Bethel at Norwich}

population, which has been seen as a characteristic of mid-nineteenth-century asylums, appears to have occurred at the Bethel much earlier. I have suggested that economic factors such as income from fee-paying patients (or the lack of it) and inflation appear to have influenced the running of the trust as much as clinical need, and that where there were changes in clinical practice these were related as much to professional and administrative issues as to patient need.

Despite the limitations of records made for contemporary administrative purposes and not designed for rigorous clinical analysis, we can derive some insight into the world of the patients at the Bethel in the eighteenth century. In general, discharged patients were twice as likely to be female as male and twice as likely to be considered recovered at the time of discharge as not. Patients could expect to be discharged eventually, and one in six returned again, sometimes frequently. Restraint was clearly an established form of management together with purges, powders, vomits, and baths, all the standard therapeutics of eighteenth-century mad-doctoring. A significant number of residents would have received physic of some kind and an unknown number physical treatments. At the same time the "moral" dimension of management was acknowledged. Patients were to be controlled, but controlled with sensitivity. Their environment and activities were well regulated, and the responsibility for this was laid firmly upon the Master and Mistress and their staff.

The Bethel was an institution which provided care for the mad over an extended period in a community which had a tradition of initiatives for the disadvantaged, beginning before the voluntary hospital era and continuing beyond it. The existing archive is limited both in what was recorded at the time and in what has survived, but what remains is an intact and unbroken record. This has allowed some insight into an earlier period of institutional care for the mad and some of the local medical, social, and political influences in its development. However, many aspects of the Bethel's history remain to be explored. 